Edisi Khusus Vol. 4 No. 3 (Desember 2021), Halaman: 237 - 246 Available Online at http://ejurnal.ubharajaya.ac.id/index.php/Jabdimas

\title{
Peningkatan Kesiapan Literasi Digital Dalam Menunjang MBKM Kampus Mengajar di Wilayah Desa Tajur Halang SD, SMP Sinar Kasih dan Masyarakat Sekitar
}

\author{
Iwan Aang Soenandi ${ }^{1, *}$, Prasasti Perangin Angin ${ }^{2}$, Benisius Anu ${ }^{1}$ \\ ${ }^{1}$ Fakultas Teknik dan Ilmu Komputer; Universitas Kristen Krida Wacana; Jl. Tanjung Duren \\ Raya No 4, Telp. 0215666952 Fax. 021566 6956; iwan.as@ukrida.ac.id, ehba@ukrida.ac.id \\ 2 Fakultas Ekonomi dan Bisnis; Universitas Kristen Krida Wacana; Jl. Tanjung Duren Raya No \\ 4, Telp. 0215666952 Fax. 021566 6956; prasasti.peranginangin@ukrida.ac.id \\ *Korespondensi: e-mail: iwan.as@ukrida.ac.id
}

Submitted: 15/12/2021; Revised: 18/12/2021; Accepted: 28/12/2021; Published: 31/12/2021

\begin{abstract}
Digital learning is a necessity in the industrial era 4.0. Students must be equipped with various skills based on information technology. Digital learning infrastructure and the ability of Human Resources (HR) for SD and SMP Sinar Kasih need attention in creating schools based on digital learning. In addition, the people of Kampung Cina where the Sinar Kasih Elementary and Middle School are located have the same needs, where the students who attend school there are free of charge for the school fees, because their vision is to serve the underprivileged communities around the Tajurhalang neighborhood and village. Problem solving is carried out through training to increase the capacity of SD and SMP Sinar Kasih human resources to carry out digital learning. The material presented is divided into two, namely creative pedagogy and digital literacy. Second, through the fulfillment of digital learning equipment, including the provision of computers, LCD projectors, training modules, increasing internet capacity, and providing video tutorials for teachers and students. This will also support the effectiveness of the implementation of the Independent Learning Campus Merdeka BKP Teaching Assistance which has been carried out by 25 Ukrida students in Sinar Kasih Elementary and Middle School.
\end{abstract}

Keywords: Digital Literacy, Teacher, Digital Infrastructure, MBKM

\begin{abstract}
Abstrak
Pembelajaran digital merupakan kebutuhan di era industri 4.0. Siswa harus diperlengkapi dengan berbagai kemampuan yang berbasis teknologi informasi. Infrastruktur pembelajaran digital dan kemampuan Sumber Daya Manusia (SDM) SD dan SMP Sinar Kasih perlu mendapat perhatian dalam menciptakan sekolah yang berbasis digital learning. Selain itu, masyarakat Kampung Cina lokasi SD dan SMP sinar kasih berada memiliki kebutuhan yang sama, dimana para siswa yang bersekolah di sana mereka tidak dipungut iuran sekolah dengan kata lain adalah gratis, karena visi mereka adalah melayani masyarakat kurang mampu di sekitar lingkungan dan desa Tajurhalang. Pemecahan masalah dilakukan melalui pelatihan peningkatan kapasitas SDM SD dan SMP Sinar Kasih untuk melaksanakan pembelajaran digital. Materi yang disampaikan dibagi dua yakni pedagogi kreatif dan literasi digital. Kedua melalui pemenuhan perlengkapan pembelajaran digital diantaranya, penyediaan komputer, LCD Projector, modul pelatihan, peningkatan kapasitas internet, dan penyediaan video tutorial bagi guru dan siswa. Hal ini juga akan menjadi penunjang efektivitas pelaksanaan Merdeka Belajar Kampus Merdeka BKP Asistensi Mengajar yang telah dilakukan oleh 25 mahasiswa Ukrida di SD dan SMP Sinar kasih.
\end{abstract}

Kata kunci: Literasi Digital, Guru, Infrastruktur Digital, MBKM 


\section{Pendahuluan}

Digital literasi menjadi sebuah kebutuhan dalam pengembangan dunia Pendidikan. Memasuki era industri 4.0 kemampuan digital menjadi sebuah keniscayaan. Perkembangan dunia membentuk kehidupan manusia telah berbasis informasi. Karena itu, dalam menyiapkan lulusan yang berkualitas dan mampu bersaing secara global, serta menguasai perkembangan teknologi merupakan hal yang sangat penting untuk semua orang dan bagi masa depan suatu Bangsa dan Negara. Oleh karena itu literasi digital perlu dikembangkan dalam dunia pendidikan sekarang ini untuk membangun karakter bangsa yang lebih baik dan lebih siap menghadapi era pendidikan abad 21 (Khasanah \& Herina, 2019).

Menjadi topik menarik mengimplementasikan pendidikan dan tantangan pembelajaran berbasis teknologi informasi di Era Revolusi Industri 4.0 dan kesiapan indonesia menjawab tantangan pendidikan era revolusi industri 4.0 dalam membangun sistem pembelajaran berbasis teknologi informasi. Di Indonesia kesiapan menghadapi tantangan pendidikan era revolusi industri 4.0 adalah segera meningkatkan kemampuan dan keterampilan sumber daya manusia Indonesia melalui pendidikan dengan melahirkan operator dan analis handal bidang manajemen pendidikan sebagai pendorong kemajuan pendidikan berbasis teknologi informasi di Indonesia menjawab tantangan Industri 4.0 yang terus melaju pesat. Kebijakan manajemen pendidikan di Indonesia saat ini mendorong seluruh level pendidikan, terutama pendidikan tinggi untuk memanfaatkan kemajuan teknologi digital dan komputasi pendidikan era revolusi industri keempat. Beberapa solusi yang bisa dilakukan antara lain, kesesuaian kurikulum dan kebijakan dalam pendidikan, kesiapan SDM dalam memanfaatkan ICT, mengoptimalkan kemampuan peserta didik, dan mengembangkan nilai - nilai (karakter) peserta didik, serta dan kesiapan sarana dan prasarana pembelajaran berbasis digital (Syamsuar \& Reflianto, 2018).

Maka tidak dapat dielakan digital literasi menjadi sebuah kebutuhan dalam pengembangan dunia pendidikan. Keterbatasan infrastruktur digital menjadi salah satu penghambat dalam pencapaian digital literasi di sekolah sinar kasih. Hal ini juga mempengaruhi mahasiswa-mahasiswi Ukrida yang melakukan kegiatan Merdeka Belajar Kampus Merdeka (MBKM) asistensi mengajar di sinar kasih. Mahasiswa tidak dapat mengeksplorasi pembelajaran karena tidak adanya akses internet, serta perlengkapan digital lainnya seperti komputer, LCD projector, dan lain sebagainya.

Sebagai fasilitas pelaksanaan MBKM Kampus mengajar, di sekolah SD dan SMP Yayasan Sinar Kasih ini sangat memerlukan kesiapan Digital Learning agar meningkatkan manfaat dan variasi yang bisa dilakukan oleh para mahasiswa dan siswa SD serta SMP. Dari Survei yang telah dilakukan setelah para mahasiswa melaksanakan kegiatan MBKM Kampus Mengajar selama 3 bulan, sebagian besar siswa dan pengajar merasa bosan dan kurang semangat untuk belajar serta merasa kurang nyaman dengan suasana kelas. Berdasarkan Penelitian dari (Sundus, 2018) Pembelajaran secara digital dapat meningkatkan daya tarik bagi siswa SD dan SMP dibandingkan dengan pembelajaran menggunakan text book. Arti Digital 
learning adalah media pembelajaran yang dilakukan secara digital dan tanpa harus menunggu adanya akses internet untuk bisa memulai pelajaran tersebut.

Kurangnya peralatan yang mendukung suasana belajar dengan multimedia karena rendahnya daya beli Yayasan Sinar Kasih ini yang berstatus nirlaba serta memberikan layanan gratis dalam penyelenggaran pendidikan. Sekolah ini sejak berdiri tidak memungut biaya kepada siswa karena kemampuan ekonomi masyarakat sekitar sekolah sangat rendah. Hal ini tentu berdampak kepada suasana kelas yang kurang nyaman dan tidak dapat dilakukan pembelajaran digital.

Tersedianya multimedia sangat berpengaruh terhadap interaksi pembelajaran di dalam kelas. Multimedia consists of two or more media formats composed of texts, images, graphics, sounds, animations, and videos of a material or information which are then entered into a computer system so that through the media incorporated in multimedia, it is expected that learning activities would become more interactive and dynamic (Komalasari, Rahmat, \& Rahman, 2019) (Kapi Kahbi, Osman, Ramli, \& Taib, 2017).

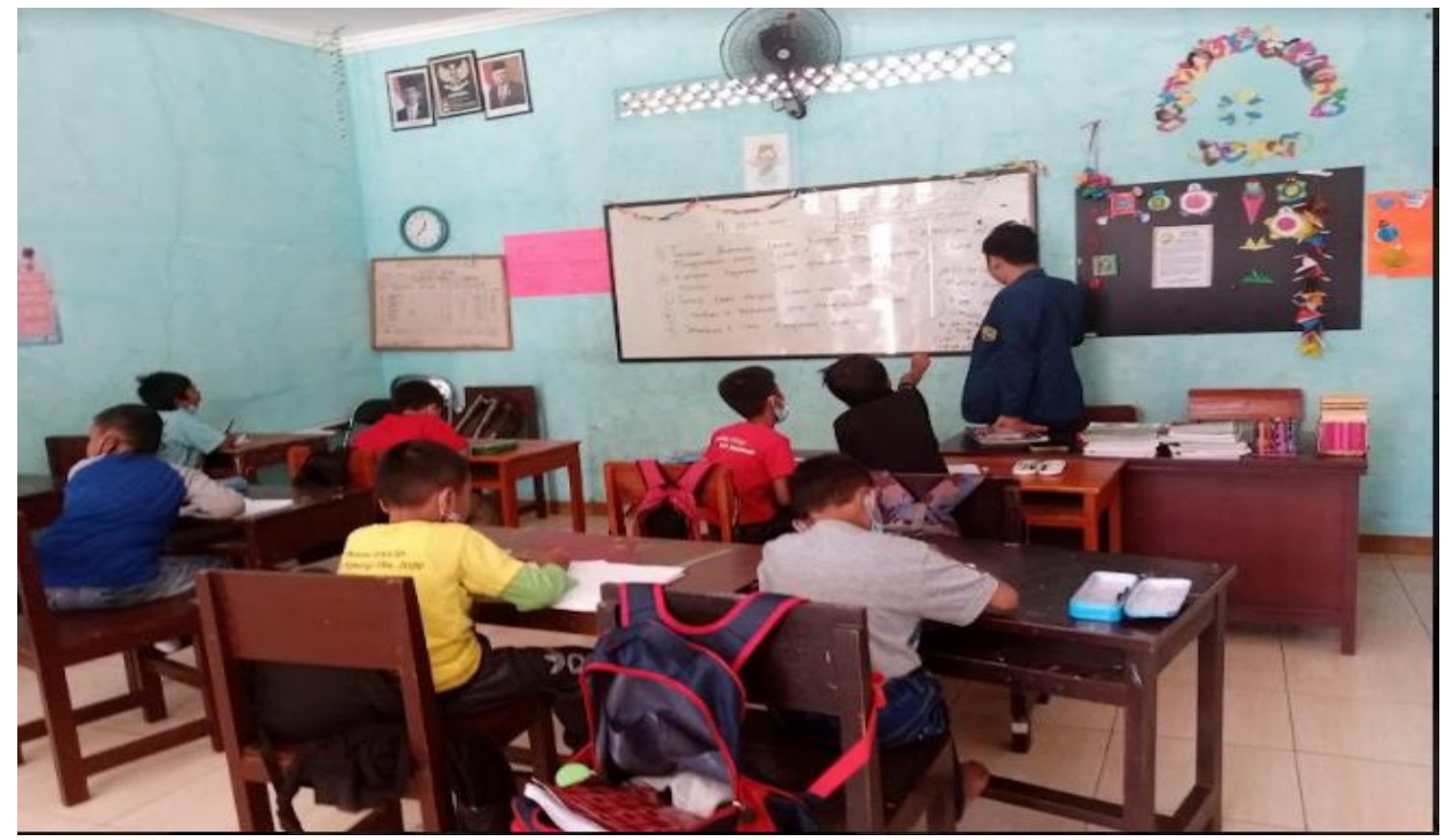

Sumber: Hasil Pelaksanaan (2021)

Gambar 1. Kondisi Kelas Sinar Kasih

Serta karena pengaruh pembatasan sosial sekolah juga perlu mengembangkan manajemen pembelajaran digital atau Learning Management System (LMS). LMS Google Classroom dibuktikan memiliki efektifitas dan respon positif dari penggunanya. Pembelajaran menggunakan Google Classroom sangat efektif, karena Google Classroom banyak mendapatkan respon positif dari siswa, mahasiswa, dan pengguna lainnya. Kelayakan Google Classroom sebagai media pembelajaran menunjukan rata-rata hasil validasi yang sangat baik, sehingga dapat dikatakan layak sebagai media pembelajaran (Hikmatiar, Sulisworo, \& Wahyuni, 2020). 
Sekolah Sinar Kasih berada di kampung cina RT 01/09 Tajurhalang Bogor Jawa Barat. Yayasan ini mengemban visi 'Kasih untuk menjangkau dan memajukan umat manusia kepada Tuhan'. Visi yayasan ini diterjemahkan dalam visi sekolah yakni 'Menjadikan lembaga pendidikan yang Seimbang dalam IImu, Iman dan Pengabdian kepada TUHAN dan sesama manusia'.

Sekolah Sinar Kasih hadir untuk memberikan layanan pendidikan gratis kepada masyarakat wilayah Kampung Cina. Ketua yayasan, Deny Sahetapy menuturkan, puji Tuhan sampai sekarang sekolah bisa berdiri tanpa memungut biaya dari siswa. Masyarakat di Kampung Cina banyak yang tidak melanjutkan pendidikan formal. Bahkan lulusan S1 dari kampung ini dapat dihitung jari, ujarnya. Karena itulah sekolah ini hadir agar orang tua mau menyekolahkan anaknya dan menjadi kesempatan bagi kemajuan anak-anak di sekitar wilayah Kampung Cina. Oleh karena itulah, pengabdian masyarakat Ukrida perlu dilakukan di Sekolah Sinar Kasih dengan judul, Peningkatan Kesiapan Digital Learning dalam Menunjang Kebijakan Merdeka Belajar Kampus Merdeka Sekolah Sinar Kasih dan Kampung Cina Desa Tajur Halang Bogor.

\section{Metode Pelaksanaan}

Pelaksanaan kegiatan dibagi menjadi dua bagian utama. Pertama, pengukuran tingkat pemahaman dari guru, siswa dan orang tua. Kedua, peningkatan kapasitas guru dalam melaksanakan digital learning melalui ceramah secara offline dan online dan yang ketiga kedua penyediaan infrastruktur dasar literasi digital.

\subsection{Pengukuran Tingkat Pemahaman Dari Guru, Siswa Dan Orang Tua}

Pengukuran ini dilakukan dengan kuesioner secara online dan bentuk kertas yang akan dilihat peningkatan pemahaman dari sebelum dan sesudah kegiatan ini

\subsection{Pelatihan Keterampilan Kapasitas Guru secara Offline dan Online}

Peningkatan kapasitas guru dibagi dalam 9 modul digital literasi. Kesembilan modul dirangkum untuk pencapaian pembelajaran aktif, inovatif, dan kreatif. Metode yang ditekankan dari semua modul dalam rangka menciptakan suasana belajar student center learning. Pembelajaran yang berpusat pada siswa mendorong siswa aktif, kritis, serta mampu mengembangkan potensi dan cara berpikir siswa. Metode ini memungkinkan siswa menemukan sendiri makna pembelajaran. Jadi bukan metode 'bank' yang menjadikan siswa objek yang harus diisi oleh guru sebagai subjek pembelajaran. Guru berperan adalah fasilitator dan menjadi pemicu inovasi. Siswa bahkan mampu memecahkan masalah dengan metode pembelajaran aktif seperti metode trade a problem (Hadijah \& Surya, 2016). Penelitian (Efendi, 2018) menyebutkan dibutuhkan revolusi pembelajaran berbasis digital yang memampukan siswa belajar secara aktif.

Modul pertama pelatihan ini membahas fondasi dasar pendidikan yakni filosofi pendidikan. Berhubung sekolah Sinar Kasih adalah sekolah gratis bagi masyarakat Kampung Cina Desa Tajur Halang, maka beberapa guru tidak berasal dari program studi keguruan. Sehingga materi fondasi ini sangat dibutuhkan untuk memberikan arah bagi para guru tentang apa itu pendidikan dan pendidik. Pemahaman ini akan melandasi seluruh proses pembelajaran 
dan pengembangan pendidikan di Sekolah Sinar Kasih. Fasilitator menggali filsafat pendidikan, pendidikan konvensional dan kontemporer, serta melatih guru memahami makna pendidikan.

Modul ini juga membahas tentang peran guru sebagai panggilan hidup yang melayani dan mengabdi bagi anak didik. Guru sebagai garda terdepan untuk mencerdaskan kehidupan bangsa memerlukan guru-guru yang melihat profesi guru sebagai profesi yang mulia, bermartabat dan merupakan panggilan hidup. Sehingga dalam seluruh pelaksanaan proses pendidikan guru mampu mentransformasi hidup siswa dalam segala aspek.

Modul kedua membahas pendidikan karakter. Muara pendidikan adalah terbentuknya karakter siswa. Hal ini juga penting diintegrasikan dengan nilai-nilai agama yang merupakan sumber utama pembentukan karakter siswa. Nilai-nilai karakter yang dibahas terintegrasi dengan nilai-nilai kristianitas atau nilai universal agama. Sebagaimana visi sekolah Sinar kasih, tidak hanya mentransfer atau mencetak generasi yang tinggi ilmu, tapi juga generasi yang tinggi iman (bertaqwa) serta mampu mencerminkan nilai-nilai karakter seperti integritas, kasih, kepedulian, serta keadilan.

Modul ketiga membahas tentang kepemimpinan seorang guru melalui games-games kreatif yang dapat memecahkan kebuntuan dalam proses pelatihan maupun proses pembelajaran di sekolah. Guru pertama-tama sebagai pemimpin yang akan melahirkan seorang pemimpin. Melalui games ini guru-guru juga diharapkan bisa lebih rileks, bermain, serta tetap konsentrasi mengikuti modul-modul lainnya.

Modul keempat membahas tentang bagaimana pemahaman filosofi pendidikan dan pendidikan karakter diterjemahkan dalam penulisan silabus yang kreatif. Hal ini akan menolong guru untuk tetap terarah untuk melihat materi pembelajaran bermuara kepada pengembangan potensi diri yang berbasis pendidikan karakter yang tercermin dalam silabus atau lesson plan setiap guru. Lesson plan atau yang dikenal dengan Rencana Pelaksanaan Pembelajaran (RPP) sering menjadi momok bagi para guru. RPP harus ditulis njelimet, panjang dan rumit yang tentunya menyita waktu bagi para guru (Mayudana \& Sukendra, 2020). Karena itu di sesi ini diharapkan guru tidak antipati terhadap lesson plan dengan membuat silabus secara kreatif dan efektif. Di sisi ini guru dilatih untuk mempraktekan bagaimana cara menterjemahkan kurikulum pendidikan kepada rencana pembelajaran yang menunjang visi dan misi pendidikan sekolah sinar kasih.

Modul lima membahas tentang bagaimana pedagogi kreatif dan penerapannya di sekolah. Guru perlu melihat bahwa kreativitas dan inovasi akan muncul bilamana guru mampu secara kreatif menerapkan pedagogi kreatif bagi siswa. Melalui pemahaman pedagogi kreatif guru diharapkan dapat mengoptimalkan perlengkapan digital yang akan dimiliki sekolah Sinar Kasih. Kunci keberhasilan pendidikan bukan di teknologinya, namun bagaimana guru secara kreatif memanfaatkan teknologi untuk mencapai tujuan. Tanpa pemahaman yang komprehensif tentang pedagogi kreatif, teknologi tidak akan bermanfaat untuk melahirkan inovasi, kreatifitas, dan daya kritis siswa. 
Pada modul keenam membahas tentang metode pembelajaran aktif yang dapat diterapkan oleh guru. Metode yang ditawarkan adalah studi kasus, demonstrasi, diskusi, berbasis projek, serta service learning. Secara khusus metode service-learning tergolong baru dalam pendidikan di Indonesia. Lebih sering dikenal sebagai kelas lapangan atau kuliah kerja nyata di pendidikan tinggi. Namun metode ini menarik untuk diterapkan oleh para guru, karena memadukan pelayanan komunitas (community service) dengan pembelajaran di kelas. Metode ini dapat melatih kepekaan sosial siswa serta melatih siswa sejak dini untuk meneliti, penerapan iptek terhadap masalah masyarakat, serta memampukan siswa untuk berlatih dalam realitas persoalan masyarakat. Metode ini dapat guru lakukan dengan cara yang sederhana seperti menugaskan siswa untuk melakukan kebersihan di rumah ibadah. Lalu setelah melakukan kebersihan di beberapa tempat ibadah, siswa ditugaskan menulis sebuah cerita pengalaman toleransi. Ini bisa menjadi penugasan pelajaran pancasila atau pendidikan kewarganegaraan sekaligus pelajaran bahasa Indonesia. Metode service-learning juga dapat meningkatkan reflective thinking (Setiawati, Karyadi, \& Yani, 2018).

Modul ketujuh membahas tentang pemahaman dasar digital literasi. Membahas tentang apa itu digital literasi, bagaimana diterapkan di sekolah, serta keunggulan pendidikan yang berbasis digital di era industri 4.0. Digital literasi memampukan siswa untuk meningkat secara kognitif dengan meningkatkan daya pikir melihat konten digital. Disamping itu juga memampukan siswa memiliki kreativitas dengan melakukan hal-hal baru atau cara-cara baru dari konten yang disajikan oleh guru. Serta memampukan siswa untuk kritis menyikapi konten-konten digital.

Modul kedelapan melatih guru untuk menyajikan kemampuan literasi digital dalam materi pembelajaran. Guru dilatih bagaimana mengintegrasikan verbal, visual, dan ragam informasi yang ada di internet. Hal ini akan memungkinkan guru untuk membuat presentasi powerpoint yang menarik, interaktif, serta inovatif.

Modul terakhir membahas tentang bagaimana mengoperasikan Learning Management System (LMS) Google Classroom. LMS ini dibutuhkan untuk menjadi sarana pembelajaran hybrid (luring dan daring) atau kelas full online yang dapat dilakukan oleh Sekolah Sinar Kasih.

\subsection{Penyediaan Peralatan Dasar Literasi Digital}

Keberadaan digital literacy bagi individu dewasa awal menjadi sebuah kemampuan yang esensial pada berbagai bidang pekerjaan, sehingga kompetensi dalam penggunaan teknologi digital menjadi sesuatu yang wajib dimiliki dalam masyarakat (Osterman, 2012)(Noh, 2016). Selain itu juga di dalam Digital Literacy ada suatu pola yang terlihat yang memerlukan penyediaan infrastruktur ini (Subarjo, 2017). Dalam mencapai tujuan memenuhi kelengkapan dasar, kegiatan pengabdian ini mengalokasikan anggaran untuk penyediaan ruang kelas siap digital. Perlengkapan yang dialokasikan adalah perlengkapan dasar dari infrastruktur Digital Learning yaitu computer desktop, Projector, Speaker Selain itu peralatan pendukung lainnya untuk pembelajaran seperti Whiteboard dan lampu 


\section{Hasil dan Pembahasan}

Pengukuran terhadap kesiapan digital learning sekolah Sinar Kasih dilakukan untuk mengetahui tingkat keberhasilan terhadap efektivitas program. Pengukuran dilakukan dengan asesmen pengetahuan untuk mengevaluasi tingkat pemahaman para guru, orang tua dan siswa terkait kesiapan digital learning. Di sini para guru, orang tua dan siswa diminta untuk mengerjakan soal pre dan post test. Adapun butir-butir pertanyaan adalah seperti pada Tabel 1 yang berisikan pemahaman guru dan orang tua terhadap pengajaran dan pembelajaran serta pembelajaran secara digital. Kami membuat butir butir pertanyaan untuk melihat pemahaman mereka terkait proses pengajaran yang mereka pahami dan esensi dari pendidikan. Selanjutnya dilanjutkan dengan beberapa pertanyaan dasar terkait Digital Learning yang mereka kenal saat ini. Dari pertanyaan di kuesioner pendahuluan terkait fasilitas, mayoritas dari mereka masih menjawab sangat kurang karena memang di sekolah gratis ini, mereka tidak sanggup membeli peralatan yang cukup mahal karena keterbatasan dana. Selain itu kami juga membuat kuesioner kepuasan masyarakat setelah program abmas ini.

Tabel 1. Pertanyaan Kuesioner

\begin{tabular}{ll}
\hline No. & Pertanyaan untuk siswa/siswi \\
\hline 1. & Metode pembelajaran yang mengasah daya berpikir siswa \\
\hline 2. & Metode pembelajaran yang mampu mendorong semangat melayani siswa \\
\hline 3. & Sikap yang harus dimiliki seorang guru dalam pengembangan materi pembelajaran \\
\hline 4. & Filosofi pendidikan yang wajib dipahami seorang guru, kecuali \\
\hline
\end{tabular}

5. Guru seyogyanya mampu melihat pekerjaan sebagai

Sumber: Hasil Pelaksanaan (2021)

Gambar 2 menunjukkan hasil pre test dari hasil jawaban responden yang telah mengisi kuisioner.

$\begin{array}{ccc}\text { Average } & \text { Median } & \text { Range } \\ 30 / 100 \text { points } & 30 / 100 \text { points } & 0-70 \text { points }\end{array}$

Total points distribution

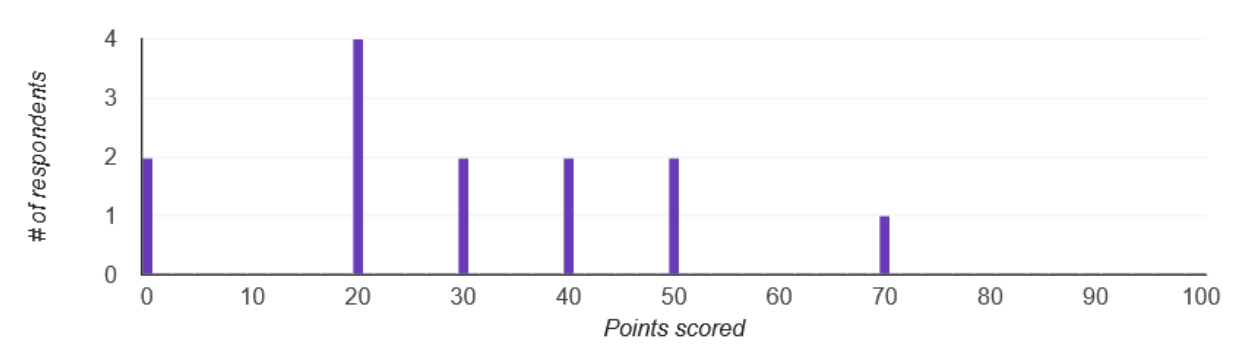

Sumber: Hasil Pelaksanaan (2021)

Gambar 2. Hasil Pengukuran Pre-Test 
Gambar 3 menunjukkan hasil post test dari hasil jawaban responden yang telah mengisi kuisioner.
Average
Median
Range
$77.78 / 100$ points
$80 / 100$ points
$50-100$ points

Total points distribution

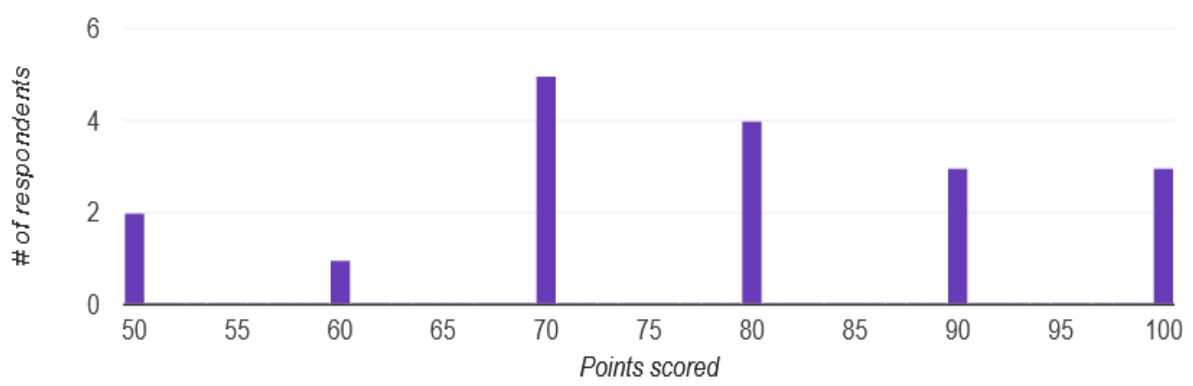

Sumber: Hasil Pelaksanaan (2021)

Gambar 3. Hasil Pengukuran Post-Test

Dari Gambar 2 dan 3 dapat dilihat peningkatan yang cukup besar pada pemahaman tentang proses pengajaran dan pemahaman Digital Learning karena ada beberapa responden yang mendapatkan nilai 90 dan bahkan 100 .

Dari hasil pengisian responden sebanyak 131 peserta yang terdiri dari guru, orang tua dan siswa yang hadir secara offline dan online didapatkan hasil $89,3 \%$ dari responden merasakan kegiatan pengabdian masyarakat ini sangat relevan dengan kebutuhan saat ini.

Materi sangat relevan dengan kebutuhan Bapak/lbu saat ini

131 responses

150

100

50

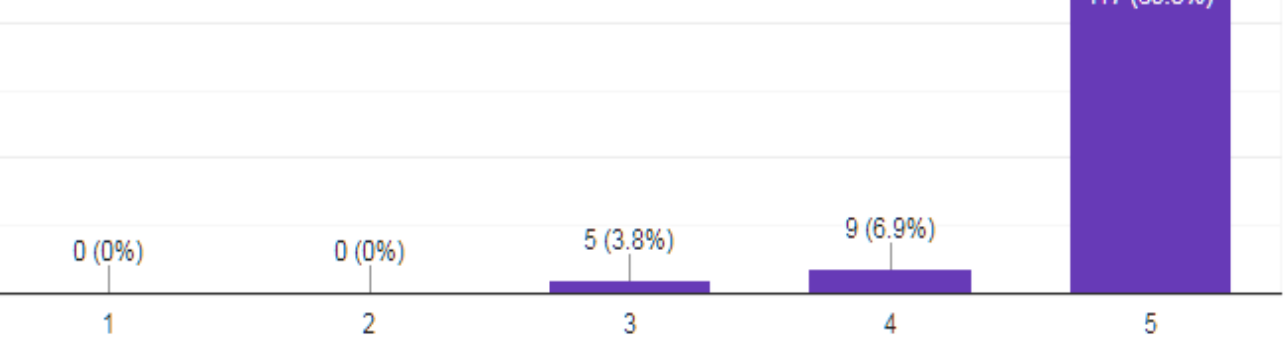

Sumber: Hasil Pelaksanaan (2021)

Gambar 4. Hasil Kepuasan Masyarakat 


\section{Kesimpulan}

Terjadi peningkatan kemampuan literasi guru SD dan SMP Sinar Kasih setelah mengikuti peningkatan kapasitas literasi digital. Guru-guru semakin memahami makna Pendidikan dan bagaimana Pendidikan aktif di era digital dapat diterapkan di ruang kelas. Kemampuan guru dalam pelaksanaan literasi digital dimulai dari pemahaman makna filosofi Pendidikan, Pendidikan karakter, kepemimpinan interaktif, kemampuan untuk membuat silabus efektif, pedagogi kreatif, metode pembelajaran aktif serta pemahaman digital literasi, keterampilan pembuatan media pembelajaran yang kreatif dan pengoperasian LMS Google Classroom. Melalui kesembilan modul ditemukan bahwa guru-guru Sinar Kasih semakin memahami makna pendidikan, digital literasi, metode pembelajaran interaktif, dan bagaimana merancang pembelajaran digital. Hal ini diperkuat dengan perlengkapan berupa alat-alat digital seperti LCD, komputer, jaringan internet, disiapkan sebagai infrastruktur Digital Learning. Sekolah Sinar Kasih sebagai sarana pendidikan gratis untuk masyarakat Kampung Cina Desa Tajur Halang siap untuk bersaing untuk menyelenggarakan pendidikan yang berkualitas. Hal ini juga terlihat dari tingkat kepuasan masyarakat Kampung Cina Desa Tajur Halang terhadap pelaksanaan pendidikan di SD dan SMP Sinar Kasih. Meskipun sekolah sinar kasih sekolah gratis namun sekolah yang mampu bersaing untuk melaksanakan pendidikan berbasis digital. Akhirnya fasilitas sekolah dan kemampuan guru sekolah gratis ini juga mampu untuk menerapkan LMS yang terintegrasi dengan pembelajaran. Melalui itu materi ajar dan pembelajaran menjadi lebih efektif dan efisien, serta memberi dampak positif bagi perkembangan masyarakat Kampung Cina Desa Tajur Halang.

\section{Ucapan Terima Kasih (Opsional)}

Terima kasih disampaikan kepada semua pihak yang telah membantu kegiatan pengabdian masyarakat ini. Pertama kepada Kementerian Pendidikan, Kebudayaan, Riset, Dan Teknologi melalui pendanaan bantuan hibah bantuan pendanaan program penelitian kebijakan merdeka belajar kampus merdeka dan pengabdian masyarakat berbasis hasil penelitian dan purwarupa PTS dari Direktorat Jenderal Pendidikan Tinggi dan Riset dan Teknologi tahun anggaran 2021. Kedua terima kasih kepada Sekolah Sinar Kasih Bogor serta masyarakat melalui Kepala Desa Tajur Halang, Ketua RT 1 dan seluruh pihak yang membantu kegiatan ini dapat berlangsun

\section{Daftar Pustaka}

Efendi, N. M. (2018). Revolusi Pembelajaran Berbasis Digital (Penggunaan Animasi Digital Pada Start Up Sebagai Metode Pembelajaran Siswa Belajar Aktif). 2(2), 173-182.

Hadijah, S., \& Surya, E. (2016). Pengaruh Penggunaan Metode Pembelajaran Trade A Problem Terhadap Kemampuan Pemecahan Masalah Siswa Kelas VIII MTSN Tanjung Pura Materi Kubus Dan Balok T.A. 2013 / 2014. AdMathEdu: Jurnal IImiah Pendidikan Matematika, IImu Matematika Dan Matematika Terapan, 6(1). https://doi.org/10.12928/admathedu.v6i1.4763 
Hikmatiar, H., Sulisworo, D., \& Wahyuni, M. E. (2020). Pemanfaatan Learning Manegement System Berbasis Google Classroom Dalam Pembelajaran. Jurnal Pendidikan Fisika, 8(1), 7886. https://doi.org/10.26618/jpf.v8i1.3019

Kapi Kahbi, A. Y., Osman, N., Ramli, R. Z., \& Taib, J. M. (2017). Multimedia education tools for effective teaching and learning. Journal of Telecommunication, Electronic and Computer Engineering, 9(2-8), 143-146.

Khasanah, U., \& Herina. (2019). Membangun Karakter Siswa Melalui Literasi Digital Dalam Menghadapi Pendidikan Abad 21 (Revolusi Industri 4.0). Prosiding Seminar Nasional Pendidikan Program Pascasarjana Universitas PGRI Palembang, 21, 999-1015.

Komalasari, I., Rahmat, A., \& Rahman, T. (2019). Exploring undergraduate students mental representation and its correlation with information processing and their knowledge in learning plant transport using diagram convention. Journal of Physics: Conference Series, 1157(2). https://doi.org/10.1088/1742-6596/1157/2/022106

Mayudana, I. K. Y., \& Sukendra, I. K. (2020). Analisis Kebijakan Penyederhanaan Rpp (Surat Edaran Menteri Pendidikan Dan Kebudayaan Nomor 14 Tahun 2019). IJED (Indonesian Journal of Educational Development), 1(1), 62-70. https://doi.org/10.5281/zenodo.3760682

Noh, Y. (2016). A study on the effect of digital literacy on information use behavior. Journal of Librarianship Information Science, 49(1), 26-56. https://doi.org/10.1177/0961000615624527

Osterman, M. D. (2012). Digital Skills Definition, Framework and Competencies. IFIP Advances in Information and Communication Technology, (c), 1-6.

Setiawati, N. P., Karyadi, B., \& Yani, A. P. (2018). PENGEMBANGAN LKPD IPA BERBASIS SERVICE LEARNING UNTUK PENDAHULUAN Perubahan kurikulum menuntut adanya peningkatan dalam proses pembelajaran. Kurikulum 2013 mengubah pendekatan pembelajaran yang berpusat pada guru menjadi pendekatan pembelajaran yang berp. 2(1), 76-85.

Subarjo, A. H. (2017). Perkembangan Teknologi Dan Pentingnya Literasi Informasi Untuk Mendukung Ketahanan Nasional. Angkasa: Jurnal Ilmiah Bidang Teknologi, 9(2), 1. https://doi.org/10.28989/angkasa.v9i2.188

Sundus. (2018). The Impact of using Gadgets on Children. Journal of Depression and Anxiety, 07(01), 1-3. https://doi.org/10.4172/2167-1044.1000296

Syamsuar, \& Reflianto. (2018). Pendidikan dan Tantangan Pembelajaran Berbasis Teknologi Informasi di Era Revolusi Industri 4.0. Jurnal IImiah Teknologi Pendidikan, 6(2), 1-13. 